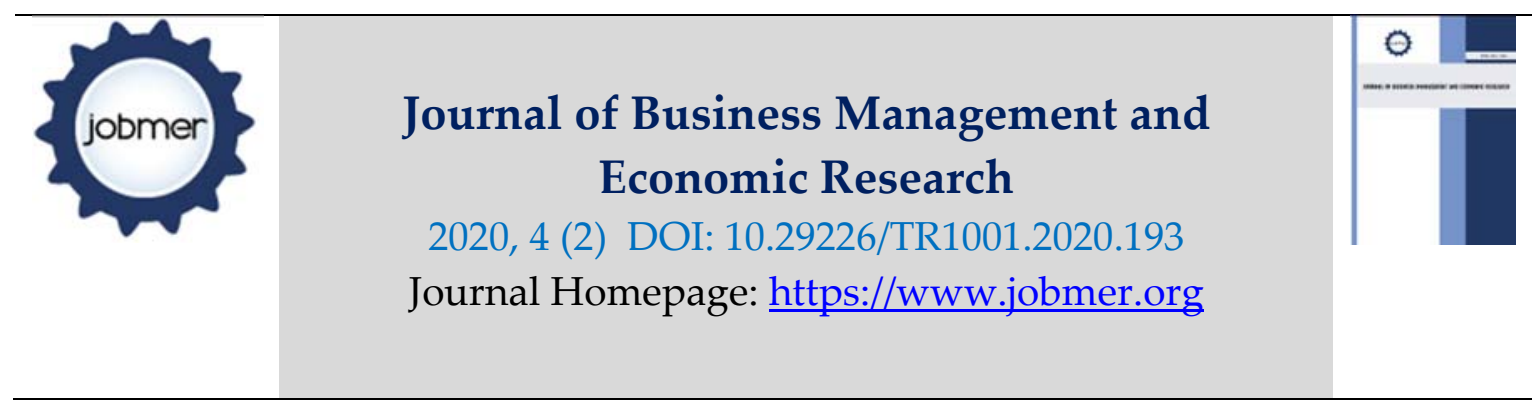

\title{
Mediating Effect of Investment Decisions between Overconfidence Heuristic and Financial-Performance of Small, and Medium Enterprises in Nairobi, Kenya
}

\author{
Alex Koech ${ }^{a^{*}}$, Josphat Cheboi ${ }^{a} \&$ Naomi Koske ${ }^{a}$ \\ ${ }^{a}$ Finance and Accounting depatrment, Moi University, Kenya \\ ${ }^{*}$ Corresponding author's email:drfernando173@gmail.com
}

\begin{abstract}
Investors' thinking and feeling have emotional impact on their behavior when making investment decisions. These impacts are identified as behavioral heuristics. They affect all investors and vary subject to the investor's nature. This, in turn, affects the financial-performance of the SME. Heuristic behavior is an essential part of the decision-making process which profoundly influences the investor's financial performance. Heuristic factors play an undeniable role in influencing persons' decisions, which includes investment decisions. The study seeks to scrutinize the outcome of the Overconfidence heuristic on financial-performance and also analyze the mediational effect of investment decisions on the link concerning the Overconfidence heuristic and financial-performance of the SMEs in the County of Nairobi. The heuristic theory guided this study. Anchoring on Explanatory research design, the study targeted 64,443 SMEs, with sample size being 382 SMEs. This research used a stratified sampling design. Data were collected using structured questionnaires and items were anchored on a five-point Likert scale. Descriptive and inferential statistics were used as analysis tools. The test for hypotheses was done using multiple regression models and Hayes process macro for mediation. The regression results presented that Overconfidence heuristic had positively significantly affect financial-performance $(\beta=.156, p<.05)$. Besides, Investment Decision had a positively and significantly mediating effect on the relation between Overconfidence Heuristic and Financial-Performance $(\beta=.289, \mathrm{p}<.05, \mathrm{CI}=0.001,0.076)$. This study contributes new knowledge to the theories. There is a need for SME owners/managers to understand and effectively how to use investment decisions to improve their financial-performance. Furthermore, researchers need to undertake comparative studies covering other geographical locations to make generalizations from this study.
\end{abstract}

Keywords: Heuristic behavior, Overconfidence, Investment decisions, Financial performance.

\section{Suggested Citation:}

Koech, A., Cheboi, J. \& Koske, N. (2020). Mediating Effect of Investment Decisions between Overconfidence Heuristic and Financial-Performance of Small, and Medium Enterprises in Nairobi, Kenya. Journal of Business Management and Economic Research (JOBMER), Vol: 4, Issue: 2, 186-198. 


\section{Introduction}

Financial performance is the practice of determining the outcomes of a firm's policies and processes in monetary terms over a certain time (Jayawardhana, 2016). It pinpoints the financial prowess and weakness of a firm by creating relationships amongst the items of the financial position and income statement as noted by Jayawardhana, (2016), profitability; return on equity; and liquidity ratios among others provide valuable tools or measures to stakeholders to assess the past and current financial-performance of a firm. Profitability is an indicator of how a company's financial performance is relative to its total cost assets.

Small and Medium Enterprises play a role in most economies through the world which measures their financial-performance (Kinyua, 2014). Eniola \& Entebang (2016) found out that unfavorable government policies influence negatively SMEs financial-performance with decreasing issuance of total credit by both commercial and merchant banks to SMEs. Profit is a proxy to measure the financial-performance of SMEs. According to Tambunan et al., (2011), SMEs are an important driver for economic development and the empowerment of local communities. Even though SMEs provide a solution to various economic problems, they also face challenges from other dimensions that dissuade their financial-performance and therefore inhibit their growth.

Overconfidence heuristic is the propensity of investors to either overestimate their abilities or underestimate other abilities or difficulty of the task (Rasheed et al, 2018). It is a cognitive heuristic where people have an superfluous faith in their instinctual reasoning; judgments; and cognitive abilities (Pompian and Wood, 2006).

\section{Theoretical review.}

This research was informed by Heuristic theory; it is a tenet, which an individual use in an uncertain situation to make decisions easy and resourceful (Ritter, 2003). Kahneman and Tverskys, (1979) detected that irrational individuals used heuristics in their decision-making since they fail to judge the impeccable probability. Heuristics are beneficial when the period for decision is limited and there is incomplete information (Waweru et al., 2008). John M. Keynes, (1936) and Irving Fisher, (1930), reasoned that investments are made till the present value of predictable future returns, at the margin, and the opportunity cost of capital are equal. This means that investment is done until the net present value is comparable to zero. An investment is anticipated to produce a river of future cash flows. 


\section{Conceptual framework}

This is an arrangement which the study trusts can best describe the natural development of the phenomenon to be studied (Osanloo, \& Grant, C. 2016). It's the researcher's explanation of how the research problem would be explored. The framework defines the connection between the main concepts of a study. This study seeks to establish the mediational effect of investment decisions to that link between heuristic behavioral factors and the financial-performance of SMEs in the County of Nairobi.

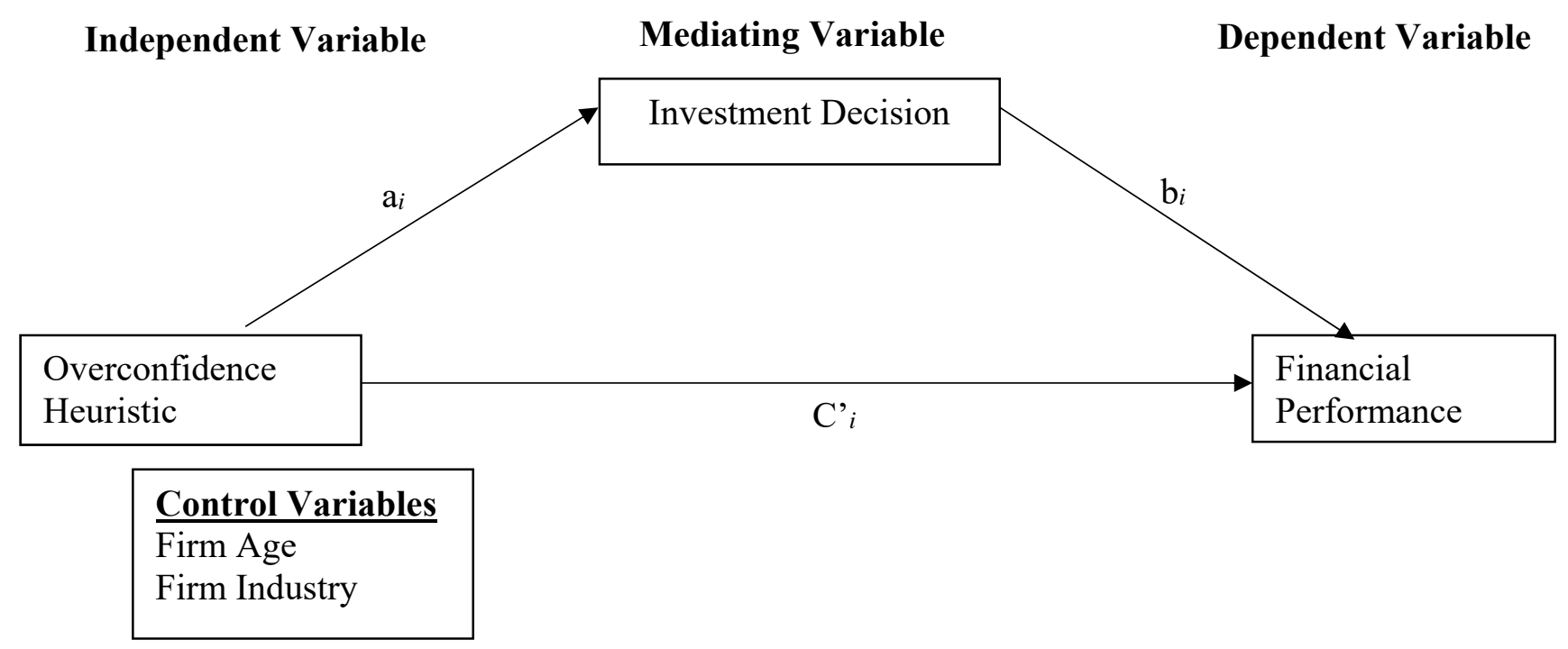

Figure 1: Conceptual Framework

Source; Author (2020)

\section{Hypotheses}

During the study, it was hypothesized that:

$H_{01}$ Overconfidence heuristic has no significant effect on the financial-performance of SMEs in Nairobi County, Kenya'.

$\mathrm{H}_{\mathbf{0} 2}$ Investment decisions do not mediate the association between overconfidence heuristic and the financial-performance of SMEs in Nairobi County, Kenya.

\section{Methodology}


This study is in line with the positivism approach of paradigm, which pursues to use existing theory to deduce and formulate variables. The study adapted explanatory design of research of a cross-sectional nature which analyses the cause effect association between variables (Creswell \& Creswell, 2017). The design was suitable to the study since it sought to investigate a cause-effect relationship of the three constraints, which are, Financial-Performance, Overconfidence Heuristic and Investment Decision.

The study target population constituted 64,443 SMEs as registered and licensed by the County government of Nairobi. The researcher targeted the owner/ manager in each of the SMEs as its unit of observation therefore the sample size being 382 SMEs. Stratified sampling and simple random techniques were used to choose the sample. The study used structured questionnaires to collect data for dependent, mediating and independent variables, where each of the items was subjected to Five-point Likert scale, from 1=Strongly Disagree to $5=$ Strongly Agree. The entire scales of the study had been authenticated in previous literature. However, while all scales were adopted, they were amended to suit the setting of this research study. Financial performance was measured following previously developed methods by (Al-Matari, et al., 2014). Furthermore, Overconfidence heuristic was measured using items developed by (Babajide and Adetiloye, 2012), and (Luong and Thu Ha, 2011). Also, Investment Decision measurements were selected from Pachur, et al., (2008) and Scott and Bruce, (1995). Finally, Firm age was measured as the sum of years the firm has been in existence that is the ordinal scale from 1 to 4 (Chun. et al., 2016).

The reliability of the instruments was tested using the internal stability technique by employing a Cronbach Alpha rate of 0.7. Internal and external validity was assessed to establish whether the instrument truly measures what it is projected to measure (Taber, 2018). Descriptive and inferential statistic tools were used to analyze data. Descriptives were the mean; standard deviation; Skewness; and Kurtosis, while inferential statistics was the Pearson correlation coefficient testing the relationship and strength between the variables. Multiple regression models were used to check the hypotheses for the study.

\section{The regression model:}

Direct Effect.

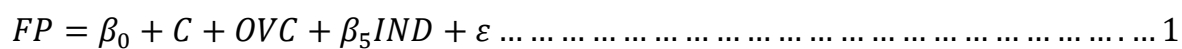

Mediational model (indirect effect).

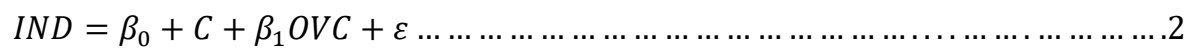

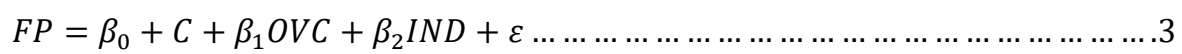

Direct Effect: $B_{2}\left(C^{\prime}\right)$ 
Indirect Effect: $\beta_{1} * \beta_{3}(a x b)$

Total effect: $\beta_{2}+\left(\beta_{1} * \beta_{3}\right)$

\section{Results}

Table 1 below shows the alpha coefficient for reliability tests.

Table 1. Reliability' of the Study Variables

\begin{tabular}{lcc}
\hline Variables & Cronbach's Alpha & N \\
\hline Financial Performance & 0.815 & 7 \\
Overconfidence Heuristic & 0.837 & 8 \\
Investment Decision & 0.893 & 6 \\
\hline
\end{tabular}

Source: Research Data, (2020)

The outcomes demonstrate that Investment Decision recorded the highest reliability ( $\alpha=0.893)$, followed by Overconfidence heuristic, with a coefficient of $(\alpha=0.837)$ and finally, Financial performance had a reliability score of $(\alpha=0.815)$. The reliability coefficients were above the recommended value (0.7) showing consistency in measuring the constructs as per (Taber, 2018).

The study conducted Pearson correlation analysis to establish the link between the variables. Correlation coefficient value ( $\mathrm{r}$ ) ranging from 0.10 to 0.299 was considered weak, from 0.3 to 0.49 was considered average and from 0.5 to 1.0 were considered strong (Wong and Hiew, 2005). According to Field, (2005), the correlation-coefficient should not be in excess of 0.8 to avoid multi-collinearity. In this test, the null hypothesis was zero for the correlation-coefficient (no relation). Consequently, the null-hypothesis will be rejected if the level of a significance test is below 0.05 .

The regression test for both control and independent-variables (direct effect) was done. The hypotheses tested the effect of Overconfidence Heuristic on financial-performance (DV) of Small; and Medium Enterprises in Nairobi County, Kenya. The results in Table 2 below show that all the predictors explain $51.7 \%$ of the variation on financial performance, where (R-squared $=0.517$, Adjusted R-squared $=0.508$ ). The findings also showed that the coefficient of determination was significant as shown by $F=103.79, \mathrm{p}$ $<0.001$. For the control variables, the firm size was non-significant but the industry $(\beta=0.591, \mathrm{p}<0.05)$ the results showed that it significantly influence the financial-performance. 
The $1^{\text {st }}$ hypothesis $\left(\mathrm{H}_{01}\right)$ states that Overconfidence Heuristic has no significance on the FinancialPerformance of SMEs in Nairobi County, Kenya and from the findings in table 2 below, the null hypothesis is rejected. The findings reveal that Overconfidence Heuristic has positively and significantly effected Financial-Performance, $\beta=0.156, p<0.001$, where ( $p$-value $=0.000$ which is below $\alpha=0.05$ ). Since there is the low p-value associated with the $t$ ratio, the null hypothesis is rejected.

Table 2: Coefficients of estimates

\begin{tabular}{|c|c|c|c|c|c|c|c|}
\hline & \multicolumn{2}{|c|}{$\begin{array}{l}\text { Unstandardize } \\
\text { d Coefficients }\end{array}$} & \multicolumn{2}{|l|}{$\begin{array}{l}\text { Standardize } \\
\text { d } \\
\text { Coefficients } \\
\end{array}$} & \multicolumn{3}{|c|}{$\begin{array}{l}\text { Collinearity } \\
\text { Statistics }\end{array}$} \\
\hline & \multicolumn{3}{|c|}{ Std. } & \multirow[b]{2}{*}{$\mathrm{T}$} & \multicolumn{3}{|c|}{ Toleran } \\
\hline & B & Error & Beta & & Sig. & ce & VIF \\
\hline (Constant) & 2.368 & .136 & & 17.454 & .000 & & \\
\hline Operational years & .060 & .032 & .084 & 1.897 & .059 & .934 & 1.070 \\
\hline Industry & .400 & .030 & .591 & 13.321 & .000 & .934 & 1.070 \\
\hline OVCAVE & .182 & .050 & .156 & 3.619 & .000 & .779 & 1.283 \\
\hline \multicolumn{8}{|l|}{ Summary statistics } \\
\hline $\mathrm{R}$ & .719 & & & & & & \\
\hline R Square & .517 & & & & & & \\
\hline Adjusted R Square & .508 & & & & & & \\
\hline Std. Error of the Estimate & .424 & & & & & & \\
\hline Durbin- Watson & 1.996 & & & & & & \\
\hline ANOVA (F stat) & 103.79 & & & & & & \\
\hline Sig & .000 & & & & & & \\
\hline
\end{tabular}

Dependent Variable: Financial Performance

Source: Research Data, (2020)

The study established the Mediational Effect of Investment decisions on the relation between Overconfidence Heuristic and the financial-performance of the SMEs in Nairobi County. The study used Hayes 4 model to achieve the mediational effect and performed regression analysis on the Overconfidence variable using PROCESS macro version 3.2 (Hayes, 2018). MacKinnon's (2012) four-steps were followed to study the mediation effect. The study pursued to determine:

1. The power of Overconfidence Heuristic on Investment-decision indicated as path "a $i$ " (Figure 1)

2. The influence of Investment Decisions on Financial-performance, path " $\mathrm{b}_{i}$ " (Figure 1).

3. The effect of Overconfidence Heuristic on Financial-performance while controlling for Investment Decisions, path $\mathrm{C}_{i}^{\prime}$ (Figure 1). 
4. Lastly, the indirect path between Overconfidence Heuristic and Financial-performance via Investment Decisions $\left(\mathrm{a}_{\mathrm{i}} \times \mathrm{b}_{\mathrm{i}}\right)$. The bias-revised percentile bootstrap method decides whether the last condition is satisfied. Covariates (Firm Age, Firm Industry) were all included in the analysis.

Step 1, indicated as Table 3 (Model 1), established that Overconfidence Heuristic significantly affected performance with $\beta=.165, p<.05$. In step two, presented as (Model 2), Investment-Decisions were found to statistically and significantly affect performance with, $\beta=.194, \mathrm{p}<.05$. Moreover, in the same Model 2 , the third step was tested while regulating for Investment-decisions. The study postulated that Overconfidence Heuristic was statistically found to have a significantly positive effect on performance with, $\beta=.289, \mathrm{p}<0.05$. The firm age and industry covariates were found to be significant with $\beta=.058, \beta=0.353, p<0.05$ respectively.

Finally, results for the bias-revised percentile bootstrap method indicate (Table 3, Model 3) that the indirect outcome of Overconfidence heuristic on financial-performance via investment decision was significant $\left(\mathrm{a}_{i} \times \mathrm{b}_{i}\right), \beta=.032, \mathrm{CI}=[.000, .076]$. The indirect effect model indicates a partial mediation between Overconfidence heuristic and financial-performance via investment decision. Furthermore, Model 4 (Table 3) reveals the total effect $\left[C^{\prime}+(a \times b)\right]$ of the findings with Overconfidence heuristic having a $\beta=.321, p<.05$. Results further indicate that the nature of firm industry covariate affects financial-performance with $\beta$ $=.376, \mathrm{p}<.05$ while firm age did not show any significance. Based on the above results, the hypothesis of this research was supported by the study findings. The implication of the findings showed that there was a partial mediation effect because the confident level of the interval is a non-zero.

Table 3: Mediational Effect of Investment Decision on Overconfidence Heuristic and FinancialPerformance link of SMEs in Nairobi County

\begin{tabular}{|c|c|c|c|c|c|c|c|c|}
\hline Predictors & $\begin{array}{c}\text { Model } 1 \\
\text { (IND) }\end{array}$ & & $\begin{array}{c}\text { Model } 2 \\
\text { (FP) }\end{array}$ & & $\begin{array}{c}\text { Model } 3 \\
\text { a1×b1 }\end{array}$ & & Model 4 & \\
\hline & B & PV & B & PV & & & $\beta$ & $\mathbf{P v}$ \\
\hline Constant & 3.087 & $(.000)$ & 0.529 & $(.028)$ & & & 1.128 & $(.000)$ \\
\hline Firm age & -.083 & (.069) & 0.058 & (.044) & & & .042 & (.160) \\
\hline Industry & .115 & $(.007)$ & .353 & (.000) & & & .376 & $(.000)$ \\
\hline OVCAVE & .165 & (.019) & .289 & (.000) & $.165 \times .194$ & $=.032$ & .321 & $(.000)$ \\
\hline INDAVE & - & - & .194 & $(.000)$ & & & - & - \\
\hline $\mathrm{R}$ & .211 & & .707 & & & & .675 & \\
\hline R2 & .045 & & .500 & & $\mathrm{CI}=.000$ & .076 & .455 & \\
\hline $\mathrm{F}$ & 5.226 & & 83.85 & & & & & \\
\hline Sig. & $(.002)$ & & $(.000)$ & & & & (.000) & \\
\hline
\end{tabular}


Level of confidence for the confidence intervals in the output: 95

The bootstrap samples number for percentile bootstrap confidence intervals: 5000 .

Source: Research Data 2020.

\section{Discussion}

The current study provides an important research model in understanding the mediational part of Investment decisions on the association between the Overconfidence Heuristics and Financial-performance of SMEs in Nairobi County.

The outcomes of this research study indicate that Overconfidence Heuristic improved financial performance. The positive product of the relationship could be associated with the fact that many SMEs use psychological aspects in their investment-decisions and therefore positively affect the financialperformance of the firm.

The more self-confident investors are the more informed decision actions they can make. In business, decisiveness is very important to catch great opportunities. Confident investors probably utilize their skills and knowledge in certain circumstances to better the investment results. Barber and Odean (2001), argued that overconfidence is paramount for difficult tasks and predictions with low predictability. From the path coefficient, overconfidence heuristic is a robust predictor of Financial-Performance. The investment decision was positively allied to financial-performance. The indirect effect through Investment Decision has partial mediational relation between overconfidence; and financial-performance.

\subsection{Theoretical and managerial implications.}

Theoretically, this research confirms the theory used and contributes to the existing literature. The study first confirms what has already been established by other scholars that overconfidence heuristic has a significant direct effect on Financial-performance and Investment-decisions of Small; and Medium Enterprises. Additionally, the study brings in some new knowledge that the Investment-decisions mediate the connection between the Overconfidence heuristics and Financial-performance of the SMEs. Besides the individual investors who may benefit directly from the outcomes of this study, the small; and medium enterprises can use these findings as reference for their research and forecast of the trends of the investment market. Our results have significant hands-on implications for individual investors, securities organizations, and behavioral finance study. Specifically, our finding shows that the Overconfidence heuristics strongly affect Investment decisions hence affecting the financial performance. Decision-makers 
should be acquainted to the heuristic behavioral biases. Investors can use the study to better understand the effect of Overconfidence heuristics on individual investment-decisions and to develop models that relate the critical factors of heuristics to have informed individual investment decisions. Moreover, both national and global financial regulatory authorities, the government and supervisory agencies are likely to have a superior understanding of the SMEs by appreciating the behavioral nature and investment decision patterns of the investors in this sector. Lastly, this paper is one of its kind in emerging economies, examining the meditational-role of Investment decisions on the link-between Overconfidence heuristic and financial-performance using the highly rigorous method of PROCESS macro for analysis.

\section{Recommendations}

This study pulls an overall picture of the impact of Overconfidence Heuristic on the financial performance and also the mediating effect of the investment decisions on the association between Overconfidence Heuristic and the financial performance within Nairobi County. The future researchers ought to focus on the challenges that the investors face in the process of making investment decisions. A study could also be done to assess the effect of other factors that could affect SME investment decisions apart from the heuristic factors reflected in this study.

\section{Acknowledgment}

The authors are extremely grateful to Moi University for her administrative and technical support in the process of this study.

\section{References}

Acheampong, P., Agalega, E., \& Shibu, A. K. (2014). The effect of financial leverage and market size on stock returns on the Ghana Stock Exchange: evidence from selected stocks in the manufacturing sector. International journal of financial research, 5(1), 125.

Alchian, A. A. (1955). The rate of interest, Fisher's rate of return over costs and Keynes' internal rate of return. The American Economic Review, 45(5), 938-943.

Al-Matari, E. M., Al-Swidi, A. K., \& Fadzil, F. H. B. (2014). The measurements of firm performance's dimensions. Asian Journal of Finance \& Accounting, 6(1), 24.

Archer, Charles J., Michael A. Blocksome, Philip Heidelberger, Sameer Kumar, Jeffrey J. Parker, and Joseph D. Ratterman. "Heuristic status polling." U.S. Patent 7,958,274, issued June 7, 2011.

Babajide, A. A., \& Adetiloye, K. A. (2012). Investors' behavioural biases and the security market: An empirical study of the Nigerian security market. Accounting and Finance Research, 1(1), 219-229.

Baddeley, M. (2017). Investment: Theories and Analyses. Macmillan International Higher Education. 
Baker, H. K., \& Ricciardi, V. (2014). Investor behavior: The psychology of financial planning and investing. John Wiley \& Sons

Baker, M., \& Wurgler, J. (2013). Behavioral corporate finance: An updated survey. In Handbook of the Economics of Finance (Vol. 2, pp. 357-424). Elsevier.

Barber, B. M., \& Odean, T. (2000). Trading is hazardous to your wealth: The common stock investment performance of individual investors. The journal of Finance, 55(2), 773-806.

Barber, B. M., \& Odean, T. (2001). Boys will be boys: Gender, overconfidence, and common stock investment. The quarterly journal of economics, 116(1), 261-292.

Benartzi, S., \& Thaler, R. (2007). Heuristics and biases in retirement savings behavior. Journal of Economic perspectives, 21(3), 81-104.

Blasco, S., \& Pertold-Gebicka, B. (2013). Employment policies, hiring practices and firm performance. Labour Economics, 25, 12-24.

Bokpin, G. A., \& Arko, A. C. (2009). Ownership structure, corporate governance and capital structure decisions of firms. Studies in Economics and Finance.

Brabazon, T. (2000). Behavioural Finance: A new sunrise or a false dawn. 28th August.

Busenitz, L. W., \& Barney, J. B. (1994, August). Biases and heuristics in strategic decision making: Differences between entrepreneurs and managers in large organizations. In Academy of Management Proceedings (Vol. 1994, No. 1, pp. 85-89). Briarcliff Manor, NY 10510: Academy of Management.

Chandra, A., \& Kumar, R. (2011). Determinants of individual investor behaviour: An orthogonal linear transformation approach.

Chen, G., Kim, K. A., Nofsinger, J. R., \& Rui, O. M. (2007). Trading performance, disposition effect, overconfidence, representativeness bias, and experience of emerging market investors. Journal of Behavioral Decision Making, 20(4), 425-451.

Ciszewska-Mlinaric, M. (2016). Foreign market knowledge and SME's international performance: Moderating effects of strategic intent and time-to-internationalization. Entrepreneurial business and economics review, 4(4), 51-66.

Creswell, J. W., \& Creswell, J. D. (2017). Research design: Qualitative, quantitative, and mixed methods approaches. Sage publications.

Daniel, K., Hirshleifer, D., \& Subrahmanyam, A. (1998). Investor psychology and security market underand overreactions. the Journal of Finance, 53(6), 1839-1885.

Dixit, A. K., Dixit, R. K., \& Pindyck, R. S. (1994). Investment under uncertainty. Princeton university press.

Eklund, J. E. (2013). Theories of investment: a theoretical review with empirical applications. In Swedish Entrepreneurship Forum (p. 2).

Eniola, A. A., \& Entebang, H. (2016). Financial literacy and SME firm performance. Int. J. Res. Stud. Manag, $5(1), 31-43$.

Evans, P. (2006). Scaling and assessment of data quality. Acta Crystallographica Section D: Biological Crystallography, 62(1), 72-82. 
Journal of Business Management and Economic Research (JOBMER), Vol.4, Issue.2, pp.186-198

Field, A. P. (2005). Is the meta-analysis of correlation coefficients accurate when population correlations vary?. Psychological methods, 10(4), 444.

Fischhoff, B., Slovic, P., \& Lichtenstein, S. (1977). Knowing with certainty: The appropriateness of extreme confidence. Journal of Experimental Psychology: Human perception and performance, 3(4), 552.

Fisher, I. (1930). Theory of interest: as determined by impatience to spend income and opportunity to invest it. Augustusm Kelly Publishers, Clifton.

Ganbold, B. (2008). Improving access to finance for SME: international good experiences and lessons for Mongolia (Vol. 438). Institute of Developing Economies.

Gervais, S., Heaton, J. B., \& Odean, T. (2003). Overconfidence, investment policy, and executive stock options. Rodney L. White Center for Financial Research Working Paper, 15(02).

Gervais, S., Heaton, J. B., \& Odean, T. (2003). Overconfidence, investment policy, and executive stock options. Rodney L. White Center for Financial Research Working Paper, 15(02).

Hayes, A. F., \& Preacher, K. J. (2014). Statistical mediation analysis with a multicategorical independent variable. British journal of mathematical and statistical psychology, 67(3), 451-47

Hayes, A. F. (2018). Partial, conditional, and moderated moderated mediation: Quantification, inference, and interpretation. Communication Monographs, 85(1), 4-40.

Hsiao, S. H., \& Su, S. H. (2006). An evaluation of investment performance and financial standing for life insurers in Taiwan. The Journal of American Academy of Business, 10(1), 278-284.

Hsiao, S. C., \& Pi-Chuan, S. (2006, October). The influence of investor psychology on disposition effect. In 9th Joint International Conference on Information Sciences (JCIS-06). Atlantis Press.

Innocenti, A., Rufa, A., \& Semmoloni, J. (2010). Overconfident behavior in informational cascades: An eyetracking study. Journal of Neuroscience, Psychology, and Economics, 3(2), 74.

Jahangir, N., \& Begum, N. (2008). The role of perceived usefulness, perceived ease of use, security and privacy, and customer attitude to engender customer adaptation in the context of electronic banking. African journal of business management, 2(2), 32.

Jayawardhana, A. (2016). Financial Performance Analysis of Adidas AG. European journal of business and management, 8(11), 74-82.

Jorgenson, D. W. (1963). Capital theory and investment behavior. The American Economic Review, 53(2), 247259.

Kapse, D., Shashank, S., \& Keswani, M. (2010). What Explains the Market: Finance Theories or Psychology?. Quest-Journal of Management and Research, 1(1), 43-54.

Keynes, J. M. (1936). Fluctuations in Net Investment in the United States. The Economic Journal, 46(183), 540547.

Kinyua, A. (2014). Factors affecting the performance of SMEs in Juakali sector in Nakuru town town. Journal of business and management volume 16 (1), 53-62.

Kumar, S. M. (2002). An introduction to Buddhism for the cognitive-behavioral therapist. Cognitive and Behavioral Practice, 9(1), 40-43. 
Le Luong, P., \& Thi Thu Ha, D. (2011). Behavioral factors influencing individual investors' decision-making and performance.: A survey at the Ho Chi Minh Stock Exchange.

Ledwith, A., \& O'Dwyer, M. (2009). Market orientation, NPD performance, and organizational performance in small firms. Journal of Product Innovation Management, 26(6), 652-661.

Lowies, G. A., Hall, J. H., \& Cloete, C. E. (2015). The role of market fundamentals versus market sentiment in property investment decision-making in South Africa. Journal of Real Estate Literature, 23(2), 297314.

Lowies, G. A., Hall, J. H., \& Cloete, C. E. (2015). The role of market fundamentals versus market sentiment in property investment decision-making in South Africa. Journal of Real Estate Literature, 23(2), 297314.

MacKinnon, D. (2012). Introduction to statistical mediation analysis. Routledge.

Markowitz, H. (1952). The utility of wealth. Journal of political Economy, 60(2), 151-158.

Mckague, K., Wheeler, D., Cash, C., Comeault, J., Ray, E., \& Tambunan, T. T. H. (2011). Development of small and medium enterprises in a developing country. Journal of Enterprising Communities: People and Places in the Global Economy.

Ngui, T. K., Elegwa, K., \& Hazel, G. G. (2014). Effect of employee resourcing on the performance of commercial banks in Kenya. International Journal of Education Research, 2(1), 1-20.

Nofsinger, J. R. (2017). The psychology of investing. Routledge.

Odean, T. (1999). Do investors trade too much?. American economic review, 89(5), 1279-1298.

O'Dwyer, M., \& Ledwith, A. (2009). Determinants of new product performance in small firms. International Journal of Entrepreneurial Behavior \& Research.

Ombongi, P. N., \& Long, W. (2018). Factors affecting financial performance of small and medium enterprises (SMEs): A case of manufacturing SMEs in Kenya. International Journal of Research in Business Studies and Management, 5(1), 37-45

Osanloo, A., \& Grant, C. (2016). Understanding, selecting, and integrating a theoretical framework in dissertation research: Creating the blueprint for your "house". Administrative issues journal: connecting education, practice, and research, 4(2), 7 .

Pachur, T., Hertwig, R., \& Steinmann, F. (2012). How do people judge risks: availability heuristic, affect heuristic, or both?. Journal of Experimental Psychology: Applied, 18(3), 314.

Park, H., \& Sohn, W. (2013). Behavioral finance: A survey of the literature and recent development. Seoul Journal of Business.

Park, H., \& Sohn, W. (2013). Behavioral finance: A survey of the literature and recent development. Seoul Journal of Business.

Pompian, M. M., \& Wood, A. S. (2006). Behavioral Finance and Wealth Management: How to Build Optimal Portfolios for Private Clients.

Pompian, M. M., \& Wood, A. S. (2006). Behavioral Finance and Wealth Management: How to Build Optimal Portfolios for Private Clients. 
Pompian, M. M. (2011). Behavioral finance and wealth management: how to build investment strategies that account for investor biases (Vol. 667). John Wiley \& Sons.

Rasheed, M. H., Rafique, A., Zahid, T., \& Akhtar, M. W. (2018). Factors influencing investor's decision making in Pakistan. Review of Behavioral Finance.

Rashid, A., \& Saeed, M. (2017). Firms' investment decisions-explaining the role of uncertainty. Journal of Economic Studies.

Riordan, M. A., Kreuz, R. J., \& Blair, A. N. (2018). The digital divide: conveying subtlety in online communication. Journal of Computers in Education, 5(1), 49-66.

Ritter, J. R. (2003). Behavioral finance. Pacific-Basin finance journal, 11(4), 429-437.

Sahi, S. K., Arora, A. P., \& Dhameja, N. (2013). An exploratory inquiry into the psychological biases in financial investment behavior. Journal of behavioral finance, 14(2), 94-103.

Schmidt, U., \& Zank, H. (2012). A genuine foundation for prospect theory. Journal of Risk and Uncertainty, 45(2), 97-113.

Scott, S. G., \& Bruce, R. A. (1995). Decision-making style: The development and assessment of a new measure. Educational and psychological measurement, 55(5), 818-831.

Sharmistha, G., \& Tanupa, C. (2018). Active investment and investing actively: an empirical study of Indian stock market. Вестник Санкт-Петербургского университета. Менеджмент, (2).

Shefrin, H. (2015). The behavioral paradigm shift. Revista de Administração de Empresas, 55(1), 95-98.

Taber, K. S. (2018). The use of Cronbach's alpha when developing and reporting research instruments in science education. Research in Science Education, 48(6), 1273-1296.

Taticchi, P., Tonelli, F., \& Cagnazzo, L. (2010). Performance measurement and management: a literature review and a research agenda. Measuring business excellence.

Tversky, A., \& Kahneman, D. (1979). Prospect theory: An analysis of decision under risk. Econometrica, 47(2), 263-291.

Waweru, N. M., Munyoki, E., \& Uliana, E. (2008). The effects of behavioural factors in investment decisionmaking: a survey of institutional investors operating at the Nairobi Stock Exchange. International Journal of Business and Emerging Markets, 1(1), 24-41.

Wong, C. C., \& Hiew, P. L. (2005, August). Correlations between factors affecting the diffusion of mobile entertainment in Malaysia. In Proceedings of the 7 th international conference on Electronic commerce (pp. 615-621).

Yamanaka, K., Chun, S. J., Boillee, S., Fujimori-Tonou, N., Yamashita, H., Gutmann, D. H., ... \& Cleveland, D. W. (2008). Astrocytes as determinants of disease progression in inherited amyotrophic lateral sclerosis. Nature neuroscience, 11(3), 251-253. 